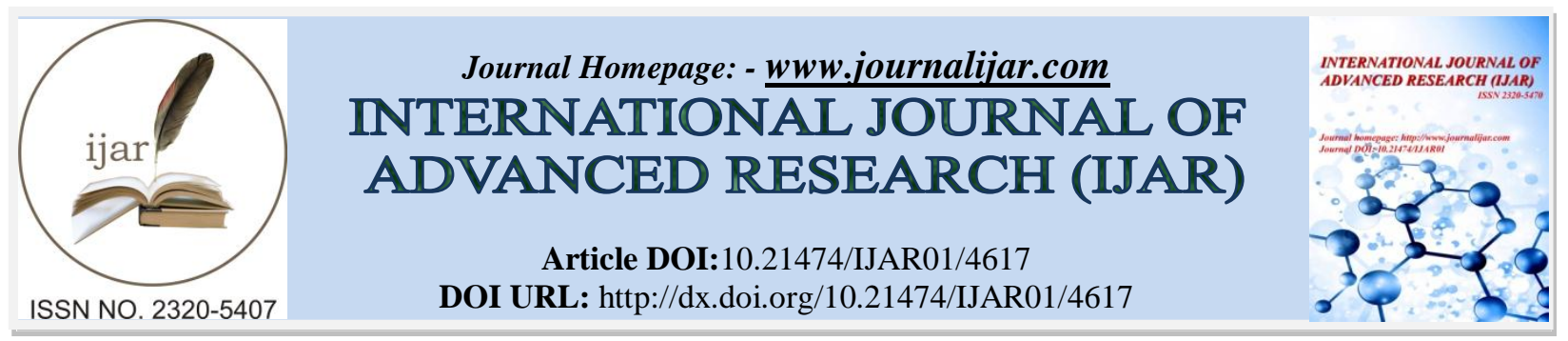

RESEARCH ARTICLE

\title{
BRAND IMAGE: AWARENESS OF SENSORY BRANDING AND ITS EFFECT ON PURCHASE BEHAVIOUR OF CONSUMERS.
}

\section{Ankita Verma ${ }^{1}$ and Kushendra Mishra ${ }^{2}$.}

1. Research Scholar, School for Management Studies, Babasaheb Bhimrao Ambedkar University (A central University), Lucknow.

2. Associate Professor, School for Management Studies, Babasaheb Bhimrao Ambedkar University (A central University), Lucknow.

\section{Manuscript Info}

\section{Manuscript History}

Received: 26 April 2017

Final Accepted: 28 May 2017

Published: June 2017

Key words:-

sensory branding, brand image, five senses, advertisements, consumer behaviour

\section{Abstract}

In developed countries people are more conscious about their Branding pattern .Brand makes one product different from competitors . In marketing one of the vital tool is Branding which differentiate brand image and its identity from one another. Sensory branding is intended to plea the human five senses, to engross feelings and so to encourage purchasing behavior. For building brand image various Companies uses different ideas for bestowing their brand by bring together unique advertisements. Sensory branding includes five senses, with the help of these senses how disparity can be created with respect to challengers becomes very easy. The objective of this paper is to spread awareness of sensory branding among consumers on emotional level which is more immersive by considering all the five senses together and to see the responds of which sense among five is more useful and its effect on purchase behavior of consumers.

Copy Right, IJAR, 2017,. All rights reserved.

\section{Introduction:-}

Sensory marketing is well-defined as a mode of assessing and elucidating consumer emotions, feelings and sentiments. Branding is one of the best portent for all developed brands in the past. The ancient Romans and Greeks were marked their wine pots and oil lamps with symbols to indicate the origin and quality of those goods. All through the industrial revolution there was vast gap in communication between the producer and the consumer, due to which the significance of branding as a means of collaborating the quality and identity of the product becomes necessary and also keeping in mind the differentiation from competitors in a market (Chernatony \& McDonald 1998, Room 1998).

In today's developed countries people are very conscious towards brand which matches their lifestyle .For attracting lot of customer it is very essential to build good brand image in consumer's mind which can result from them in brand loyalty. Market is inundated with new brands coming with their uniqueness, among which some of the brands are also attached to consumer's emotions. Therefore establishing brand uniquely can construct positively brand image in consumers mind. In this research paper by using the five senses (taste, smell, touch, hearing and sight) trying to know that how consumer perceive different types of product with different senses. Companies therefore doing all those efforts by which they will able to understand consumer and attitude by keeping in mind differentiation point of view from competitors in market. In recent time branding has turn out to be very popular due 
to the contribution of five senses - taste, touch ,hearing, sight, and smell .Earlier, most of the companies focused only on two senses which were (hearing and sight). However now they are trying to use five senses to distinguish them from the competitors. Hence, sensory branding known as branding which benefit the company to discriminate their brand and products from the competitors. Sensory branding allows the company to use of new communication channels. By using only audiovisual impetus is not sufficient for distinguishing a brand to the customer in the contemporary condition. According to Lindström, combination of all the five senses "entire sensory involvement would at least duple, if not treble, the consumer's capability to remember the brand." (Lindström 2005, pp. 23). The main aim of sensory branding is to combine all the five senses together at the same interval to build a fivedimensional know-how for the consumers.

It is understandable to identify brand, consumer must use more than one sense to recognize a brand. To construct brand consciousness and brand image(identity) in such a competitive market companies should prerequisite innovative methods to encourage prospective consumers.

\section{Purpose of study:-}

The purpose of the study is to examine awareness of customers with respect to sensory branding. How much people are aware with five senses purchase behavior and how they are emotionally attached with particular brand. Therefore, Brand Image can be built by spreading cognizance of sensory branding and its after effect on consumer purchase behavior.

\section{Objectives:-}

1) To study attachment of brand with respect to emotional value .

2) To examine impact of brand image and loyalty towards it .

3) To inspect awareness of sensory branding and its effect on customers.

\section{Research Methodology:-}

In this research paper information is collected through (paper-based sources) includes journals, research reports and magazines, therefore this study is purely based on secondary data .

\section{Theoretical Underpinnings:- \\ Sensory Branding;-}

In forthcoming years building a strong brand will shift from two senses (hearing and sight) method to Multisensory method (Lindström, 2005, pp 7). In Today's competitive market companies are concentrating on sensory stimulus to build influential brand. Many Companies enthused from a common brand building which was only two dimensional to a sensory brand structure known as five dimensional (five human senses) branding. They are directing on all the five senses to response a multidimensional aspiration from the consumers (Lindström, 2005). Each Brand create strong memories in consumers mind by alluring to all five senses. As a result leads a strong connection among brands and consumer, which further results in brand loyalty.

Therefore, time to time companies should be aware of what new going in market as well as changes in the buying behavior of customer, as behavior change is connected with all the five senses. To build a strong sensory branding there is a need of creating brand on an emotional level by using all the five senses in purchasing procedure (Lindström, 2005). It is very imperative to emphasis on ability to see and sound to communicate the uniqueness of a particular brand. Nevertheless, as it is very clear to build strong brand it is very important to assimilate the all five senses to make an emotive condition with brand so as to give a unforgettable experience to the customer. Brand experience can be believed to be as feelings, emotional state, opinions, and behavioral responses aroused by the human five senses (Djurovic, 2008). Therefore, it is obvious the more consumer will implicate with all five sense ,they will able to reminisce the brand more as a result leads to satisfaction and loyalty among customers..

\section{Brand Awareness:-}

Brand awareness is the skill of a customer to ascertain the brand in different conditions (Aaker, 1991). Else brand awareness can be defined as the capability of a customer to identify specific brand among all the other competitive brands in market. Customers always prefer those brands with which they are aware and have confidence on that brand. Therefore marketers should distinguish their product by giving particular identity. Customers while making buying decision focuses only on such brands with which they are familiar and have trust .They never select such brands from which they are not aware generally customers do not prefer to buy an unknown brand in making 
decisions. According to Keller, brand awareness consists of brand recognition. Brand awareness is the mixture of both brand recognition as well as brand recall. Brand recognition is the ability of consumer to identify earlier awareness of brand, when brand was shown or when enquired about that specific brand .According to Aaker, brand recognition is the customer's ability to authenticate past connection with the brand when given the brand as a cue (Aaker, 1991).On the other hand, brand recall is the prospective of customer to recuperate a brand from customer memory when given the product type. Or it can be said that if clue given to consumers they should appropriately pull through that brand when product is categorized .It is very true if one have unfathomable consciousness of brand then that person can recall brand very easily and rapidly to recognize a brand (Keller, 1997). In order to make brand recognition and brand recall hastily the five dimensional techniques, which include five senses, will definitely work.

\section{Brand Identity:-}

In Marketing to build brand image uniqueness is essential. Brand Identity is a vigorous part for a brand. According to Kapferer, crucial element of branding is Brand Identity (Upshaw 1995).Brand identity is a elementary resource of consumer recognition and signifies the brand's discrepancy from its competitors (brand channel 2011). One of the best approaches of recognizing and distinctive a brand from competitors. In a market how to portray brand identity is necessary so as to absolutely change consumers purchase behavior, their perception and attitude. It represents how a brand wants to be identified or differentiated to the customer in the market.

\section{Conclusion:-}

From this research paper conclusion drawn was very clear that with help of five senses (taste, touch, hearing, smell, sight) together brand can be more memorable and strong brands can be established with good brand image.The research was accompanied to understand the influence of senses used on consumer for generating brand awareness and brand identity. Sensory brand involvement engenders certain views, feelings, opinions and sentiments to build a brand image in the consumer's cognizance. It is understood that consumers can distinguish and reminiscence brands not only by any single sense but they needed more than one sense among five to differentiate. Therefore, the practice of sensory branding is projected to be one of the best activity to build brand Image in market and to spread consciousness of brand in consumers mind.

\section{References:-}

1. Aaker, D.A. (1991), Managing Brand equity, New York: The Free Press

2. Bone, P. and Jantrania, S. (1992), 'Olfaction as a cue for product quality', Journal of Marketing, Vol. 3, July, pp. 289-96.

3. Bhimrao M. Ghodeswar (2008), Journal of Product \& Brand Management, Building brand identity in competitive markets:a conceptual mode, Volume 17 , No 1.

4. Bryman, A. \& Bell, E. (2007), Business Research Methods, Oxford: Oxford University Press. Brandchannel.com (2011), brand identity, [Online] Available from: http://www.brandchannel.com/education_glossary.asp [2011-10-12]

5. De Chernatony, L. \& McDonald, M., 1998, "Creating Powerful Brands in Consumer, Service and Industrial Markets", Butterworth-Heinemann, Oxford press.

6. Djurovic, V. (2008), Sensorial Branding - The future of brands building, [Online] Available from: http://ezinearticles.com/?Sensorial-Branding---The-Future-of-BrandBuilding\&id=1412143 [2011-10-14]

7. Evancarmichael.com, Building Brand Awareness - Use all 5 Senses, [Online] Available from: http://www.evancarmichael.com/Business-Financing/5279/Building-Brand-Awareness--Use-all- 5-Senses.html [2011-10-12]

8. Gobé, M. (2001), Emotional branding, Newyork: Allworth Press.

9. Keller(2003a), Strategic Brand Management: Building, Measuring, and Managing Brand Equity, Upper Saddle River, Prentice Hall.

10. Keller, K.L. (1997) Building, Measuring, And Managing Brand Equity. New Jersey: Prentice Hall

11. Krishna, A. (2010). Sensory Marketing: research on the sensuality of products. New York: Taylor and Francis Group.

12. Krishna, A., \& Elder, R. (2010), The Gist of Gustation, Sensory Marketing, London: Psychology Press (pp. 281-297).

13. Kotler (1973), Atmospherics as a marketing tool, Journal of Retailing, Volume 49, No 4.

14. Lindström, M. (2005). Brand Sense. New York: Free Press. 
15. Martin Lindstrom (2005), Broad sensory branding, Journal of Product \& Brand Management, Vol 14, No 2, pp $84-87$

16. Labbrand Consulting Co Ltd (2011), sensory branding, [Online] Available from: http://www.labbrand.com/brand-source/experiential-branding-using-5-senses-build-brand-equity. [2011-10-14]

17. Morrin M. (2010), Scent marketing: an overview, In Krishna, Sensory Marketing, New York: Taylor and Francis Group. (p. 78).

18. Oulton T. (1995), "Management Research for information" Management Decision, Vol.33 No.5 ,PP.63-67

19. Peck. J. (2010). Does touch matter? Insight from haptics in research marketing, In Krishna, Sensory marketing, New York: Taylor and Francis Group. (pp. 17-29).

20. Room, A. (1998), "History of Branding" in Hart, S. \& Murphy, J. "Brands: the new wealth creators", New York: New York University Press.

21. Srivastava, R.K. (2011), Understanding brand identity confusion Marketing Intelligence \& Planning, Journal of marketing, Vol. 29, pp. 340-352

22. Upshaw lynn B. (1995), Building Brand Identity, Canada: John Wiley \& Sons, Inc.

23. Uddin ,Md.Saffer (2011), The Impact of Sensory Branding (five senses) on Consumer: A Case Study on "Coca Cola".

24. Winter, A. \& Winter, R. (2003). Brain workout: Easy ways to power up your memory, sensory perception, and intelligence. New Jersey: Asja Press.

25. Wolfe, J.M., Kluener, K.R. \& Levi, D.M. (2006). Sensation and perception. Sunderland: Sinauer Associates. 